\title{
Building Form berdasarkan Sejarah Kawasan Bangunan pada Jalan Basuki Rahmat Malang
}

\author{
Abraham Mohammad Ridjal, Antariksa, Noviani Suryasari, Joko Triwinarto Santoso \\ Jurusan Arsitektur Fakultas Teknik UB \\ amridjal@gmail.com, amridjal@ub.ac.id
}

\begin{abstract}
ABSTRAK
Sejarah merupakan bukti proses perjalanan yang telah dilalui oleh manusia, demikian juga dengan sejarah kota Malang yang memiliki liku perjalanan yang cukup panjang sampai dengan sosoknya yang bisa hadir saat ini. Perubahan masa, era politik dan gejolak masyarakat di dalamnya terekam dalam guratan pena sejarah maupun kreasi artefak yang hadir sebagai saksi. Ketidak-pedulian terhadap objek-saksi sejarah merupakan salah satu upaya penghapusan rekam jejak suatu peradaban. Dengan demikian, melalui pengenalan lebih dalam mengenai identitas dan sejarah perjalanan kota Malang lewat bangunan sebagai bukti sejarah, perlu dilakukan agar citra Kota Malang bisa digali dan dimunculkan kembali sesuai dengan identitasnya. Beragkat dari identifikasi sejarah kawasan melalui kajian deskriptif-historis, kemudian diikuti dengan mengidentifikasi building form berdasarkan karakter kawasan, diharapkan karakter bangunan sebagai salah satu identitas kota agar dapat terjaga serta arah pengembangan kota selanjutnya dapat lebih disinergikan dengan pondasi sejarah yang sudah berdiri kokoh.
\end{abstract}

Kata kunci: pelestarian, sejarah, bangunan kolonial

\begin{abstract}
Human civilization had been through along with the evidence of history. The city of Malang has its own history which been proved by its buildings as the eyewitnesses. As a part of Indonesian History, Malang contributed to colonialism era in which colored this nation efforts during the independence through its buildings which became the evidence of what happened. The existence of these buildings were important for the record of history, not just political stories but also how did people acted in it. Ignorance of these could erase the history of Malang, in which could stop the transfer information about what did Malang. In this case identified and re-constructed history of Malang is needed to re-built its identity. Through this agenda by historical-description hoped Malang Identity could be found and the building form could re-arranged through its character. If this action done, development of Malang city would be synergy with its own history and identity.
\end{abstract}

Keywords: conservation, history, colonialism

\section{Pendahuluan}

1.1 Mengenal Kawasan Bersejarah di Koridor Basuki Rahmat 
Sejarah Kota Malang tidak bisa dilepaskan dari warisan keindahan alam dan arsitektural bangunannya (terutama bangunan peninggalan kolonialisme) sudah selayaknya mendapat perhatian yang layak apalagi dimasa sekarang dimana pembangunan banyak mengacu pada kepentingan ekonomi dan modernitas suatu kawasan yang akan mengancam identitas dari sebuah kota.

Malang sebagai kota terbessar kedua di Jawa Timur mempunyai sejarah yang cukup panjang, dimulai dari jaman kerajaan Singosari hingga ke masa penjajahan Belanda semuanya terekam dan terdokumentasi melalui keberadaan bangunan yang menjadi sasi sejarah kota tersebut. Diantara beberapa kawasan dan koridor jalan di kota Malang, koridor jalan Basuki rahmat (yang dulunya terkenal dengan kawasan kayu tangan) merupakan salah satu saksi sejarah dari perkembangan budaya Kota Malang yang masih menyisakan jejak-jejak sejarah tersebut.

Wilayah koridor jalan basuki rahmat kota Malang berada dalam wilayah kecamatan Klojen. Kawasan yang dulunya sangat dikenal sebagai kawasan kayu tangan ini merupakan koridor utama untuk menuju pusat kota dari arah Surabaya, hal itu juga masih terjadi sampai saat ini.

Pada masa kolonial, jalan basuki rahmat lebih dikenal dengan nama kawasan kajoe tangan. Perubahan nama jalan ini dilakukan oleh pemerintah daerah kota Malang dimaksudkan untuk meminimalisir pengaruh kolonial, pasca kemerdekaan. Nama jalan ini diambil dari nama salah satu pahlawan kemerdekaan Indonesia, seperti halnya serangkaian jalan lain di Kelurahan Klojen yang semula menggunakan nama-nama dengan sentuhan indis. Namun sebetulnya perubahan nama tersebut menyebabkan makin berkurangnya nilai kesejarahan yang ada pada kawasan tersebut.

Sebagai koridor utama yang menuju kawasan pusat kota, maka ruas jalan basuki rahmat memiliki karakteristik wilayah yang beragam. Penggunaan lahan utama di wilayah tersebut didominasi oleh peruntukan lahan perdagangan dan jasa. Namun terdapat pula beberapa penggunaan lainnya yang memiliki skala pelayanan lokal dan regional.

Pergerakan yang terjadi di kawasan basuki rahmat ini pada umumnya adalah konstan dan cukup padat, terutama frekuensi pada jam-jam sibuk (peaks hours) sebagai jalur yang digunakan untuk menghubungkan daerah-daerah yang ada di kota Malang. Pada awalnya, masyarakat kota Malang masa kolonial dulu senang berbelanja maupun sekedar jalan-jalan di kawasan ini, selain dulunya sebagai kawasan pertokoan terlengkap juga memberikan suasana nyaman bagi para pengunjungnya dengan jalur pejalan kaki yang asri dan adanya tumbuhan kayu tangan yang saat ini sudah tidak terlihat lagi.

Perkembangan yang terjadi, dengan bertambahnya jumlah penduduk dan perubahan kota, maka kawasan ini cenderung diabaikan dalam pembangunan kota Malang. Ciri khas arsitektural dan nilai sejarah kawasan yang tinggi kurang diolah secara optimal. Masyarakatnya saat ini lebih senang berbelanja atau jalan-jalan ke mall atau pusat perbelanjaan yang lain karena di kawasan basuki rahmat dinilai sudah kurang menarik lagi, hal tersebut semakin menenggelamkan salah satu warisan sejarah kota Malang.

\subsection{Konservasi Sebagai Upaya Memelihara Eksistensi Kota}

Berdasarkan Piagam Burra (1981) Konservasi didefinisikan sebagai semua kegiatan pemeliharaan suatu tempat guna mempertahankan nilai kulturnya. Konservasi mencakup pemeliharaan sesuai situasi dan kondisi setempat, dan dapat 
meliputi preservasi, restorasi, rekonstruksi maupun adaptasi. Umumnya konservasi yang dilakukan merupakan gabungan dua atau lebih upaya tersebut. Tujuannya, agar bangunan yang dilestarikan menjadi lebih efisien serta perkembangannya lebih terarah. Dengan demikian, maka pengubahan tempat-tempat menarik tetap mengacu pada nilai kesejarahannya.

Sedangkan dalam suatu lingkungan kota, obyek dan lingkup konservasi di golongkan oleh Lynch (1960) kedalam beberapa luasan sebagai berikut :

1) Satuan Areal, adalah satuan areal dalam kota yang dapat berwujud sub wilayah kota (bahkan keseluruhan kota itu sendiri sebagai suatu sistem kehidupan)

2) Satuan pandangan/visual/landscape, adalah satuan yang dapat mempunyai arti dan peran yang penting bagi suatu kota. Satuan ini berupa aspek visual, yang dapat memberi bayangan mental atau image yang khas tentang sesuatu lingkungan kota.

Penjelasan tersebut diengkapi oleh Bacon (1974) yang mengatakan bahwa Kota adalah tempat dimana kumpulan-kumpulan manusia dengan energi tertentu melakukan kegiatan dan tidak ada kaitan dengan luasan atau jumlah mutlak melainkan kepadatan permukiman, selain itu kota juga merupakan kluster-kluster dengan hirarki-hirarki tertentu serta tempat dimana terdapat pembedaan spesialisasi kerja, terjadi kemakmuran yang menyebar secara tidak merata di antara warganya sehingga timbul hirarki sosial.

Kota Hindia Belanda sebagai kota bersejarah merupakan kota yang pada awalnya berupa kota tradisional, yang kemudian karena proses kolonisasi berkembang dengan pengaruh kebudayaan masyarakat kolonial. Pengertian dari kota kolonial adalah daerah urban di dalam komunitas kolonial yang secara tipikal sebagian besar ditandai dengan pemisahan fisik, kelompok-kelompok komponen etnis, sosial dan budaya yang dihasilkan dari proses kolonisasi (Anthony D. King; 1976) atau wadah dari pluralisme budaya yang di dalamnya terdapat bagian satu budaya tertentu yang memiliki monopoli kekuasaan politis. Kota-kota Hindia Belanda tersebut merupakan perwujudan adanya proses kolonisasi yang merupakan pengukuhan dan penerapan suatu aturan terhadap orang-orang asing/pribumi yang terpisah dan tunduk pada kekuasaan mengatur selama jangka waktu tertentu (Emerson; 1968). Adapun Emerson juga menggambarkan ciri-ciri kota kolonial sebagai berikut:

1) Hasil dari kondisi kontak budaya antara kekuasaan industrialis kolonial Eropa dan ekonomi tradisional, agraris, atau berbasis keahlian.

2) Mewujudkan karakteristik spasial tertentu baik dalam hal hubungan antara permukiman-permukiman dengan budaya yang berbeda, antara masing-masing area permukiman, dan antara komponen-komponen dalam area permukiman itu sendiri.

3) Ditandai dengan adanya keanekaragaman budaya.

4) Membutuhkan dorongan untuk proses integrasi pada tingkat nasional, kultural, sosial, ekonomi dan etnis.

5) Memiliki masalah perumahan, keterbatasan sumber-sumber ekonomi, keterbelakangan sistem komunikasi, dan kekurangan infrastruktur kelembagaan yang dibutuhkan berkaitan dengan kebutuhan-kebutuhan sosial, administratif dan politis.

Wilayah koridor Jalan Basuki Rakhmad Menurut Herbert (dalam Yunus H.S, 2000) termasuk dalam golongan Void Figuratif, yaitu suatu wilayah yang memiliki 
luasan daerah terbangun (build-up area) lebih besar daripada daerah tak terbangunnya. Sedangkan wilayah tak tebangunnya sangat sedikit sekali, hanya ada di depan Gereja, itupun dimanfaatkan sebagai boulevard jalan.

Untuk menelusuri urban design suatu kota, dipilih pendekatan figure ground theory (Trancik), dalam mereka ulang bentuk struktur kota. Pendekatan ini ditemukan dengan melalui studi pencakupan tanah oleh bangunan sebagai massa solid (figur) guna mendapatkan ruang kosong (tanah/ground). Sehingga tiap kota memiliki ruang padat (solid) dan ruang kosong (Void).

Teori figure ground ini bertujuan menjelaskan struktur ruang-ruang perkotaan dalam sebuah kota dengan menetapkan suatu tahapan ruang-ruang dengan ukuran yang berbeda secara individu tetapi memiliki keteraturan antara satu dengan yang lain. Fungsinya menjelaskan struktur dan pengaturan ruang perkotaan dalam gambaran skematik dua dimensi.

Bagian dari bangunan-bangunan solid perkotaan dapat meliputi antara lain: institusi atau monumen-monumen publik, dominasi daerah blok-blok perkotaan dan bangunan yang ditata secara teratur. Sedangkan ruang void perkotaan meliputi antara lain: halaman gerbang suatu bangunan, void di dalam blok, jaringan primer jalan dan square, taman dan kebun publik serta ruang-ruang terbuka linier (biasanya dikaitkan dengan bentukan-bentukan air yang besar seperti sungai).

Setelah didapatkan data skematik dua dimensi dari pendekatan figure ground, maka pengkajian ini akan dapat mengungkap bentuk kolektif, bagan pola, ataupun struktur perkotaan sebagai suatu kombinasi solid dan void dengan memunculkan berbagai kemungkinan bentuk konfigurasi, antara lain : 1) grid (pemanggang), 2) angular (bersudut banyak), 3) curvilinier (garis lengkung), 4)radial-concentric (pola berpusat) dan 5) organik. Jika konfigurasi ini dieliminir, maka akan tampillah esensi pola kombinasi center (pusat) yang dapat berupa square/open space dan path (jalan)

\subsection{Identitas sebagai Citra Visual Kota Bersejarah}

Images merupakan produk dari sensasi yang dirasakan saat ini dan adanya memori dari pengalaman masa lampau terhadap suatu lingkungan maupun obyek rancangan, yang mana keduanya digunakan untuk mengintrepetasikan informasi yang didapatkan serta sebagai pedoman untuk bertingkah laku. Sehingga, image sangat mempunyai kepentingan emosional terhadap individu.

Enviromental image yang baik dapat memberikan rasa emosional kepada penghuni, pelaku, maupun pengamat lingkungan, sedemikian rupa sehingga individu-individu tersebut dapat membangun hubungan yang harmonis antara dirinya dengan lingkungan. Menurut Lynch (1981), faktor 'citizen' juga mempunyai peran yang sangat penting dalam membangun image dengan memberikan rasa terhadap lingkungan melalui perilaku dan daya kreatifitasnya dan image juga harus dapat memberikan kemudahan bagi individu untuk bergerak dalam lingkungan serta mengembangkan hasratnya.

Dijelaskan lebih lanjut oleh Lynch, bahwa karakter arsitektur kota diperlukan untuk memberikan pemahaman tentang identitas kota sesuai dengan potensi yang ada, ciri fisik suatu kota dapat pula menjadi identitas yang kental bagi sebuah kota, apabila ciri tersebut dominan terhadap kesan visual seseorang, serta mampu menjadi wakil dari keberadaan lingkungannya maupun kota tersebut. Bahwasanya seperti bentuk benda di alam yang mudah dikenali dengan wujud fisik yang tampak maka sebuah kota dapat dibentuk identitasnya dengan karakter yang dimilikinya melalui 
bentukan-bentukan elemen kota secara fisik sehingga dapat tampak jelas sebagai obyek yang terekam dalam kesan sebuah citra kota.

Steele (1981) menjelaskan bahwa persepsi adalah proses penerimaan informasi dalam diri individu dimana individu tersebut menerima sinyal dari setting sekitar dan kemudian mengolah informasi yang masuk ini dalam pikirannya untuk kemudian memberinya makna dan pemahaman. Dalam lingkup yang lebih luas, Rapoport (1977) menggambarkan urban images adalah merupakan rasa/sense khusus dan spesifik terhadap lingkungan,serta berada diluar kesadaran individu. Image yang dilihat sebagai representasi mental dari bagian-bagian lingkungan atau kota yang sangat dikenal yang diperoleh dari pengalaman baik secara langsung ataupun tak langsung.

\section{Pembahasan}

\subsection{Penelusuran Sejarah Perkembangan Kota Malang}

Kota Malang pada dasarnya telah eksis sejak tahun 1400an sebagai pusat dari kerajaan yang berlokasi di tikungan Sungai Brantas, ditandai dengan benteng kokoh yang dikenal dengan Kutobedah. Pada tahun 1461 Malang kemudian berada dibawah kekuasaan Islam setelah ditaklukkan oleh Sultan Demak, kemudian ditaklukkan lagi oleh Untung Surapati dan Sunan Mataram. Namun peninggalan dari beberapa penguasa Malang tersebut tidak dapat ditelusuri melalui bangunan atau struktur ruang kota karena tidak adanya bangunan yang dapat mewakili keberadaan budaya dari para penguasa tersebut, disebabkan oleh terjadinya inkontiunitas rekaman sejarah, seperti misalnya tidak ditemui istana kerajaan dengan alun-alun kota yang mengikuti kaidah kosmografi hasta brata sebagai ciri khas kota-kota kuno di Jawa

Struktur Ruang Kota Malang dengan segala elemennya yang masih dapat ditemui hingga sekarang ini adalah produk dari masa kolonial yang diawali pada tahun 1767 ketika Malang beralih ke dalam kekuasaan Belanda, secara fisik ditandai dengan didirikannya Benteng di sisi kiri sungai Brantas yang saat ini dikenal sebagai daerah Klojen. Sejak tahun 1767 sampai dengan awal tahun 1870an, Kota Malang masih merupakan Kabupaten kecil yang berpusat di alun-alun lama dengan perkembangan kearah utara (di sebelah barat Sungai Brantas), yakni daerah yang sekarang ini dikenal dengan sebutan Kota Lama, secara spasial ditunjukkan pada gambar 4.1 berikut ini :

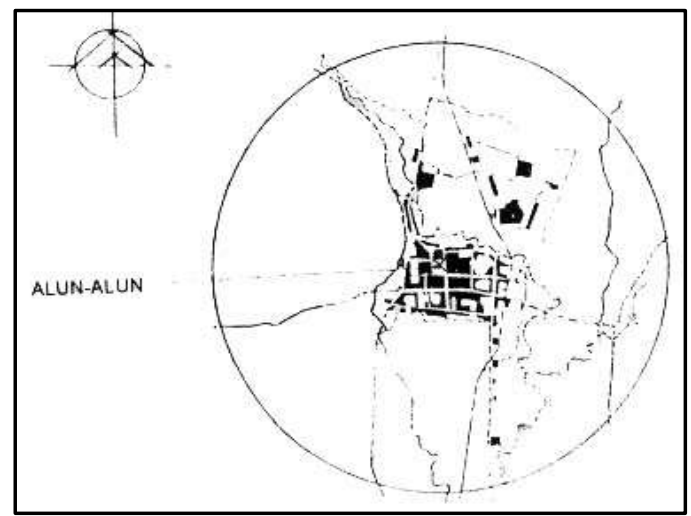

Gambar 1 Kota Lama ; Fase pertama perkembangan Kota Malang sebagai Kota Kolonial

Dikeluarkannya Undang-Undang Gula (Suikerwet) dan Undang-Undang Agraria (Agrarischwet) pada tahun 1870 telah membuka isolasi Kota Malang sebagai kota 
pedalaman dengan infrastruktur yang menghubungkan Kota Malang dengan Kota Surabaya dan Kota-kota lainnya di Jawa Timur. Akibatnya, Malang tumbuh dengan pesat. Hal ini bisa dilihat dari pertumbuhan penduduk dan perkembangan wilayah kotanya. Perkembangan wilayah kota secara spasial dapat dilihat pada gambar 4.2 yang menunjukkan perkembangan yang pesat ke arah utara kota yang berorientasi ke Kota Surabaya, meskipun demikian inti kota Malang masih berkisar di sekitar alun-alun dengan radius tidak lebih dari 2 kilometer

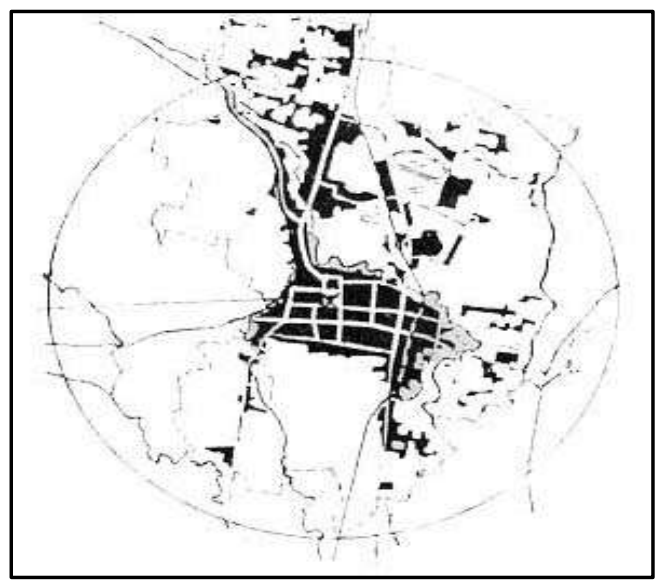

Gambar 2 Fase Kedua perkembangan Kota Malang masa kolonial menunjukkan arah pertumbuhan linier dengan aksis utara-selatan dengan Kajoetangan straat sebagai sumbu utamanya

Malang memperoleh status sebagai Kotamadya (geemente) pada tanggal 1 April 1914 dengan luas wilayah $1.503 \mathrm{Ha}$, sembilan tahun setelah Undang-Undang Desentralisasi dikeluarkan. Dalam periode 1914-1940, secara perlahan tapi pasti Malang tumbuh sebagai Kotamadya kedua terbesar di Jawa Timur. Keberhasilan pihak geemente dalam mengontrol perkembangan kota menjadikan Malang sebagai Kota yang paling teratur dan indah di Hindia Belanda pada waktu itu, dan juga tidak lepas dari sukses Perusahaan tanah Kotamadya dalam mengendalikan spekulasi tanah dari pihak swasta sehingga perkembangan kotanya bisa dikendalikan sesuai dengan rencana yang digariskan. Orang-orang dibalik perkembangan Kota Malang, diantaranya walikota pertama, HI. Bussemaker, dan penggantinya Ir. EA. Voorneman serta adviseur (penasihat) Kota Malang Ir. Herman Thomas Karsten. 


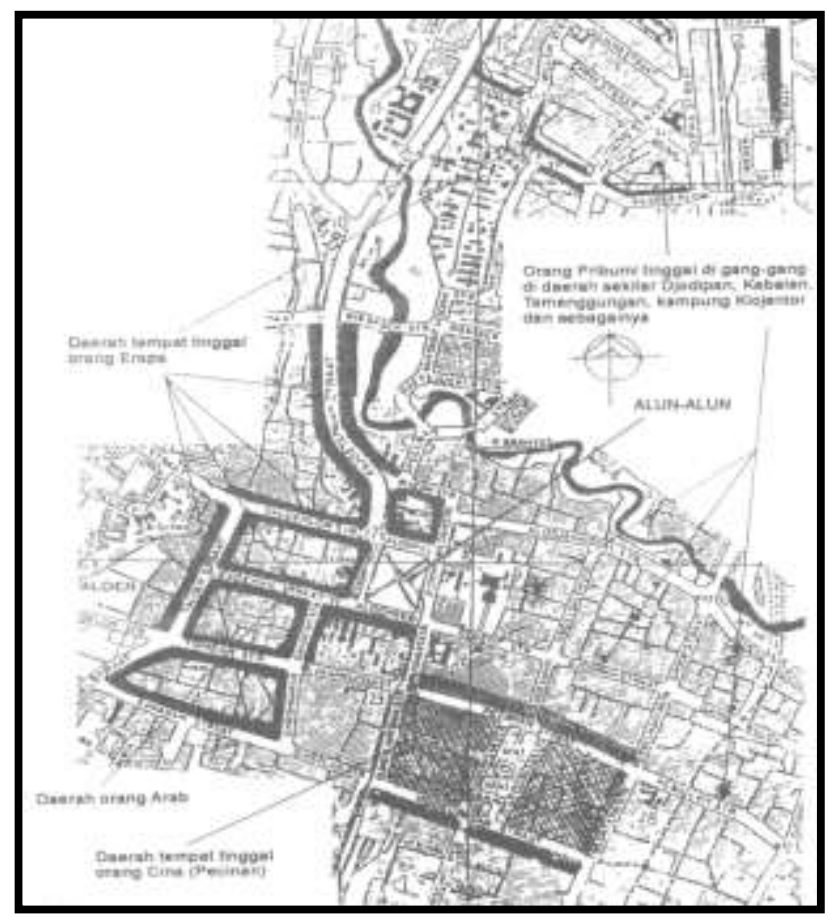

Gambar 3 Pusat Kota Malang sampai dengan tahun 1914 berada dalam radius kurang lebih $2 \mathrm{~km}$

Sedangkan perkembangan bangunan kolonial Belanda secara makro tidak berbeda jauh dengan perkembangan bangunan Hindia Belanda pada umumnya, yaitu dari perkembangan arsitektur dengan gaya Indische Empire dari masa sebelum tahun 1900an sampai datangnya arsitek profesional ke Hindia Belanda sesudah tahun 1900an yang membawa ide-ide arsitektur modern. Secara mikro perkembangan arsitektur Malang memang agak berbeda dengan perkembangan arsitektur kolonial Belanda di kota-kota lainnya. Peninggalan arsitektur dengan gaya Indische Empire di Malang sangat sedikit sekali. Hal ini disebabkan karena kota Malang sebelum tahun 1900 masih merupakan sebuah kota Kabupaten kecil, sehingga jumlah dan skala bangunan kolonialnya tidak banyak. Lagi pula lokasi dimana orang Belanda bermukim, yakni disekitar alun-alun dan Jalan Kayutangan, merupakan suatu daerah yang mempunyai kemajuan ekonomi pesat sekali sehingga bangunan-bangunan lama menjadi cepat sekali tergusur.

Dalam kaitannya dengan perencanaan Kota kolonial Malang sangat dipertimbangkan terciptanya keserasian dan keselarasan antara wajah bangunan atau lingkungan baru dengan bangunan atau lingkungan yang sudah terbentuk, sehingga tercipta kontiunitas antara lingkungan atau bangunan lama dan baru, seperti dalam perluasan kota ke arah Barat, yang tidak mengabaikan kota lama disekitar alun-alun dan pecinan, tetapi justru berusaha diciptakan hubungan kota lama dengan kota baru yang akan dibangun

\subsection{Identifikasi Historis untuk menemu-kenali Identitas Kawasan Kajoe Tangan}

Perkembangan kawasan komersial dan perkantoran di sepanjang koridor Kajoetangan straat pada masa kolonial akan diuraikan dalam dua periode yakni periode sebelum tahun 1914 dimana Kota Malang masih berstatus sebagai Kabupaten dan periode 1914-1940 yakni periode dimana Kota Malang zaman kolonial mengalami perkembangan yang pesat setelah diresmikan menjadi Kotamadya 


\section{A. Periode sebelum tahun 1914}

Permukiman di sepanjang koridor Kajoetanganstraat merupakan cikal bakal permukiman penduduk Eropa pada periode setelah masuknya Belanda tahun 1767 sampai dengan sebelum tahun 1914, seperti diuraikan dalam buku Stadsgemeente Malang berikut ini :

"Permukiman Orang Eropa terletak di sebelah Barat Daya (zuidwesten) alun-alun yang meliputi daerah Taloon, Tongan, Sawahan dan sekitarnya) selain itu juga terdapat disekitar Kayoetangan, Oro-oro dowo, Tjelaket, Klodjenlor dan Rampal"

Seperti pada kota-kota kolonial lainnya di Kota Malang juga terlihat bahwa pembangunan sarana dan prasarananya diprioritaskan untuk kepentingan kolonial seperti ditemui pada permukiman di koridor Kajoetangan straat yang saat itu telah dilengkapi dengan sarana dan prasarana yang cukup memadai bila dibandingkan dengan pemukiman untuk etnis China di kawasan Pecinan, etnis Arab di kawasan Kauman dan terutama bila dibandingkan dengan permukiman pribumi yang cenderung terabaikan.

Karakteristik bangunan di Kajoetangan straat pada periode ini menunjukkan metamorfosis yang teratur, Bangunan indis lama seperti ditunjukkan pada Gambar 4.4 dan Gambar 4.6 mewakili wajah fasade bangunan di kawasan ini sampai dengan tahun 1900. Pasca 1900an aliran-aliran arsitektural Eropa seperti art and craft serta Nieuwe Bouwen sangat mempengaruhi wajah bangunan di kawasan ini. Ciri yang paling menonjol pada bangunan kolonial yang dibangun pada periode ini adalah fasade dan denah bangunannya kebanyakan mempunyai bentuk yang simetri, disamping itu penyelesaian detail-detail bangunannya sangat rinci dan detail sekali, pengaruh aliran art and craft yang sedang berkembang di Belanda sangat dominan pada masa ini. Tetapi meskipun demikian arsitektur yang dibangun pada masa ini sudah menyesuaikan diri dengan iklim Malang, terutama terhadap sinar matahari langsung, tampiasnya air hujan dan sirkulasi udara yang baik, yang biasa diatasi dengan adanya galeri di sekeliling bangunan

Tabel 1. Karakteristik Bangunan di kawasan Kajoe-tangan era 1914

\begin{tabular}{|c|c|l|}
\hline No & \multicolumn{1}{|c|}{ Visualisasi } & \multicolumn{1}{|c|}{ Keterangan } \\
\hline 1 & & $\begin{array}{l}\text { Bangunan dengan aliran indische } \\
\text { empire } \\
\text { yang masih dapat ditemui di } \\
\text { Kajoetangaan straat hingga sekarang } \\
\text { ini }\end{array}$ \\
\hline 2 & $\begin{array}{l}\text { Elemen arsitektur tower atau menara } \\
\text { biasanya dipakai pada pintu masuk } \\
\text { atau bagian bangunan lainnya pada } \\
\text { arsitektur kolonial antara tahun } \\
\text { 1900-1915 di Hindia Belanda. Di } \\
\text { Malang, contoh yang jelas adalah } \\
\text { double tower yang ada pada landmark } \\
\text { di persimpangan } \\
\text { Kayutangan-Kahuripan. }\end{array}$ \\
\hline
\end{tabular}




\begin{tabular}{|c|c|l|}
\hline No & \multicolumn{1}{|c|}{ Visualisasi } & \multicolumn{1}{|c|}{ Keterangan } \\
\hline 3 & & $\begin{array}{l}\text { Gedung Societeit Concordia dengan } \\
\text { aliran Indische Empire dibangun pada } \\
\text { periode sebelum tahun 1914 }\end{array}$ \\
\hline 4 & $\begin{array}{l}\text { Gereja Katedral Hati Kudus Yesus } \\
\text { merupakan gereja tertua di Kota } \\
\text { Malang Desain Gereja ini mengikuti } \\
\text { aliran Neogothik yang sedang menjadi } \\
\text { trend pembangunan gereja-gereja } \\
\text { Eropa abad 19 seperti Gereja } \\
\text { Notredame di Paris dan Wetsminster } \\
\text { Abbey di Inggris. Lebar gereja ini } \\
\text { kurang lebih 11,4 m dan panjangnya } \\
\text { kurang lebih 40 m. Disisi kiri dan } \\
\text { kanan terdapat tangga yang dipakai } \\
\text { untuk naik ke lantai dua, pada kedua } \\
\text { tangga inilah pada tampak luarnya } \\
\text { dibuat dua tower (menara) yang lazim } \\
\text { ditemui pada gereja-gereja Neogothik. }\end{array}$ \\
\hline
\end{tabular}

\section{B. Periode 1914-1940}

Ketika status kota Malang ditingkatkan menjadi Geemente (Kotamadya), terjadi perluasan wewenang Gemeenteraad (Dewan Kota) untuk mengelola kotanya secara mandiri. Sehingga pada awal periode ini mulai dilakukan pembukaan Saluran air bersih pada tahun 1915 meskipun baru melayani permukiman Bangsa Eropa termasuk disepanjang koridor Jalan Kajoetangan, demikian pula untuk saluran Telepon. Peningkatan status ini juga sangat besar perannya dalam melipatgandakan penduduk Kota Malang, namun karena akses yang memadai memang paling banyak tersedia di koridor Kajoetangan straat- Tjelaket dan Lowokwaru, maka terjadi kecenderungan pertumbuhan yang hanya memanjang di koridor ini. Untuk mengantisipasi terus berkembangnya kondisi tersbut maka melalui 8 buah Bouwplan, dilakukan usaha mengatasi perkembangan yang sporadis di koridor ini.

Ciri khas bangunan-bangunan yang dibangun pada periode ini pada umumnya lebih mengutamakan segi fungsional. Aliran yang berkembang pesat di Malang pada periode ini adalah aliran Nieuwe Bouwen dengan cirikhas atap datar, gevel horizontal, volume bangunan berbentuk kubus serta warna putih, yang pada kawasan studi dapat ditemui di sepanjang koridor Kajoetangan straat dan pertokoan di perempatan Semeroe straat- Kayoetangan straat. 
Tabel 2. Karakteristik Bangunan di kawasan Kajoe-tangan era 1914-1940

\begin{tabular}{|c|c|c|}
\hline No & Visualisasi & Keterangan \\
\hline 1 & 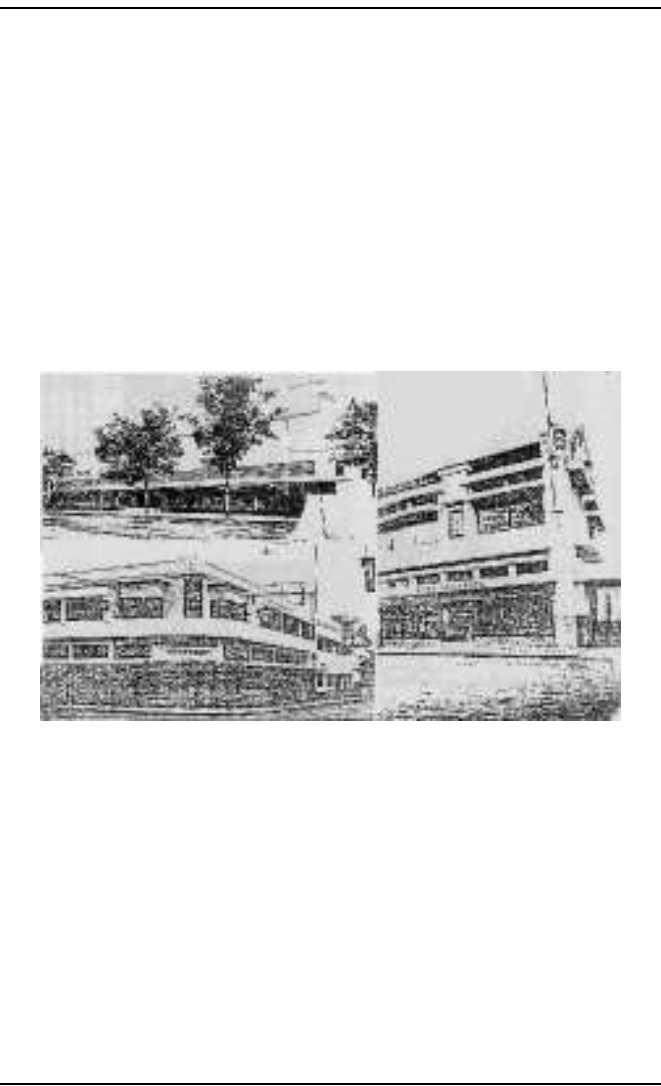 & $\begin{array}{l}\text { Pertokoan Kajoetangan Straat } \\
\text { dibangun antara tahun 1930-1940 } \\
\text { merupakan ali fungsi dari } \\
\text { perumahan kolonial pertama di } \\
\text { kawasan ini sebagai bentuk } \\
\text { penyikapan terhadap } \\
\text { perkembangan kawasan ini menjadi } \\
\text { kawasan komersial. Fasade dari } \\
\text { kompleks pertokoan ini jelas-jelas } \\
\text { menganut aliran Nieuwe Bouwen, } \\
\text { sebagian besar bangunan dilengkapi } \\
\text { dengan menara, utamanya pada } \\
\text { bangunan-bangunan yang berlokasi } \\
\text { di persimpangan jalan. Keberadaan } \\
\text { menara pada bangunan dengan } \\
\text { aliran Nieuwe Bouwen } \\
\text { menunjukkan kolaborasi yang } \\
\text { sempurna antara ciri khas } \\
\text { bangunan periode sebelumnya } \\
\text { yang direnovasi karena mengikuti } \\
\text { perkembangan trend atau karena } \\
\text { perluasan vertikal }\end{array}$ \\
\hline 2 & 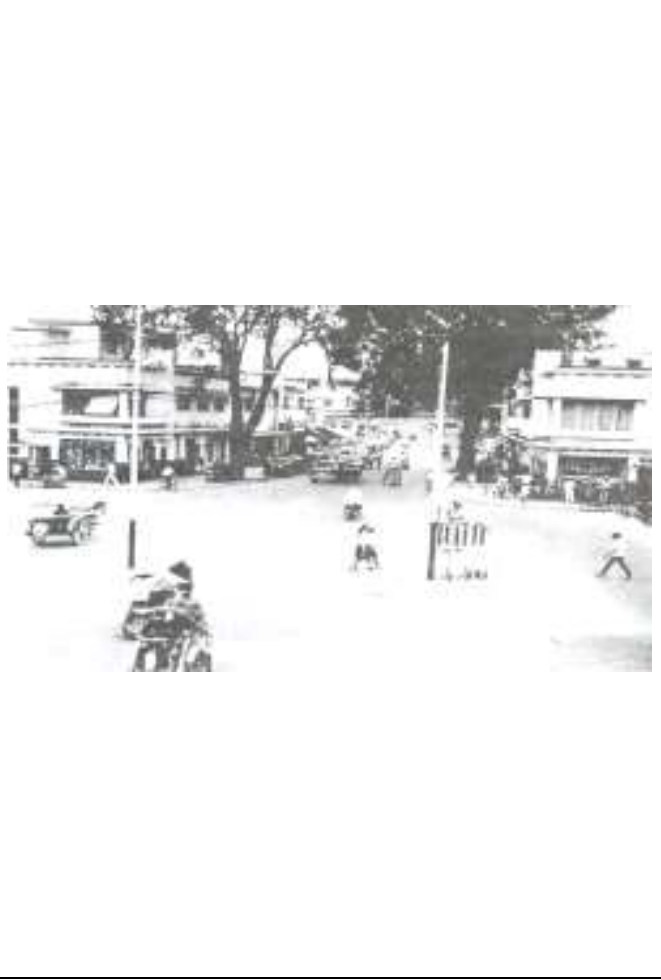 & $\begin{array}{l}\text { Prtokoan } \\
\text { Semerustraat-Kajoetangan straat ini } \\
\text { dibangun pada tahun } 1936 \text { an. } \\
\text { Arsiteknya adalah Karel Bos, } \\
\text { Bangunan pertokoan in } \\
\text { disesuaikan dengan perkembangan } \\
\text { kota setelah tahun } 1935 \text { di Malang, } \\
\text { dimana bagian pertokoan ini } \\
\text { seolah-oleh menjadi pintu gerbang } \\
\text { ke arah jalan baru menuju ke bagian } \\
\text { Barat kota yakni poros Timur Barat } \\
\text { (mulai dari jalan Kertanegara ke } \\
\text { Jalan Kahuripan memotong Jalan } \\
\text { Kayutangan, terus ke semeru dan } \\
\text { berakhir sampai jalan raya Ijen yang } \\
\text { menjadi jalan utama didaerah } \\
\text { Bergenbuurt). Gaya arsitektur di } \\
\text { pertokoan ini adalah gaya arsitektur } \\
\text { kolonial modern yang juga di kenal } \\
\text { dengan sebutan Nieuwe Bouwen }\end{array}$ \\
\hline
\end{tabular}

\subsection{Menemu-kenali Identitas Kota Malang melalui Kawasan Kayu Tangan}

Saat ini Kajoetanganstraat lebih dikenal dengan Jalan Basuki Rahmat, perubahan nama jalan ini dilakukan untuk meminimalisir pengaruh kolonial, pasca 
kemerdekaan. Nama jalan ini diambil dari nama salah satu pahlawan kemerdekaan Indonesia, seperti halnya serangkaian jalan lain di Kelurahan Klojen yang semula menggunakan nama-nama dengan sentuhan indis.

Ditinjau dari tipologi berdasarkan fungsinya, bangunan di koridor ini terdiri dari bangunan komersial dan perkantoran. Tampilan bangunan komersial dengan ciri terbuka di lantai satu, sedang lantai dua ke atas lebih di dominasi fasade masif untuk menempatkan reklame. Tampilan bangunan perkantoran dicirikan oleh ulangan unsur vertikal yang berkesan formal. Sedang kantor Bank menampilkan tipikal bentuk yang sudah ada.

Karakter bentuk bangunan di koridor jalan Basuki Rahmat dapat ditinjau dari dua aspek berikut ini :

a. Secara umum bangunan di koridor jalan ini semuanya mempunyai bentuk dasar kotak, kecuali kantor Telkom yang berbentuk perisai.

b. Ditinjau dari karakter tampangnya bangunan-bangunan di koridor ini mempunyai kesan horisontal yang kuat karena berderet menyambung menjadi satu. Disamping itu masifitasnya juga kuat oleh penggunaan bidang tak tembus pandang berupa tembok, kaca gelap dan aluminium

c. Ditinjau dari langgam arsitekturnya, bangunan-bangunan peninggalan kolonial tampil dengan permainan bidang masif dengan pelipit di bagian pinggir dan pelubangan terbatas di bagian tengahnya. Banyak bangunan kuno di koridor ini yang di tutup

Sesuai dengan fungsi kawasan yang diarahkan pada kegiatan perdagangan dan jasa, maka penggunaan lahan di kawasan studi cenderung efisien dan berkembang vertikal. Untuk mengoptimalkan penggunaan lahan, secara fisiologis bangunan pada kawasan studi dirancang sedemikian rupa agar dapat menampung kegiatan yang yang dilangsungkan di dalamnya. Agar efisiensi penggunaan lahan dapat tercapai maka dieterapkan kemunduran bangunan yang tidak terlalu besar (setelah trotoar langsung bangunan, tidak dijumpai garis sempadan depan bangunan).

Selain menentukan fungsi kawasan, menemukenali jati diri ruang kota juga harus ditelusuri peran kawasan tersebut berdasarkan sejarahnya. Ridjal (2015) berpendapat bahwa ruang arsitektur bisa dikelompokkan berdasarkan peran dan tujuannya. Selain itu, perubahan peran ruang juga akan turut serta dalam memberikan warna dan makna dari ruang tersebut. Hal ini sepertinya juga berlaku dalam menentukan tema ruang kawasan Kayutangan yang sekarang semakin tergerus oleh perkembangan kota. Dengan demikian, diperlukan langkah kongkrit dalam memunculkan kembali identitas ruang kota melalui keberadaan bangunan yang sudah lama turut mewarnai ruang tersebut.

Akan tetapi tingginya intensitas penggunaan lahan pada kawasan tidak diimbangi dengan pengembangan bangunan vertikal (karena untuk pengembangan lahan secara horizontal sudah sangat terbatas), hal ini mengindikasikan bahwa pengembangan kawasan diharapkan tidak melampaui batas, dengan kata lain ada usaha pembatasan pendirian bangunan pada kawasan. Tingginya intensitas kegiatan pada kawasan yang dihadapkan pada batasan pembangunan mendorong terciptanya suatu konsep pendirian bangunan berdasar pada efisiensi, yaitu lahirnya bangunan ruko (rumah toko).

Secara arsitektural, arsitektur bangunan pada kawasan studi saat ini sebenarnya menganut tiga macam aliran :

a. Aliran Indische Empire, yaitu bangunan dengan model eropa lama. 
b. Aliran Niuwe Bouwen, dengan cirikhas atap datar, gevel horizontal, volume bangunan berbentuk kubus serta warna putih.

c. Aliran lain yang ada di kawasan, yaitu aliran Neo Gothic yang diterapkan pada gereja Hati Kudus Kayutangan, dan juga aliran modern dengan ciri bangunan kaca atau alumunium, dan lain-lain.

Bentuk dasar pada bangunan di sepanjang koridor jalan basuki rahmat kota Malang dominan persegi empat. Hal tersebut banyak dipengaruhi oleh tipologi bangunan kolonial yang berkembang di daerah tersebut. Maka dalam perancangan bentuk fasade bangunan pertokoan di sepanjang koridor adalah bentuk dasar segi empat dengan pertimbangan sebagai berikut:

a. Tuntutan efektivitas bentuk bangunan pertokoan yang semakin tinggi dan mempertahankan bentukan dasar yang telah terbangun.

b. Adanya upaya pemaduan unsur-unsur baru dengan bangunan lama (peninggalan Belanda) yang kebanyakan berbentuk dasar segi empat simetris.

c. Sesuai dengan karakter kawasan yang ingin ditampilkan, yaitu sesuai dengan jati diri kawasan sebagai pembentuk identitas koridor jalan basuki rahmat Malang.

Analisis bentuk berdasarkan analisis obyek bangunan kolonial Belanda di Jalan Basuki rahmat Malang dilakukan dengan mendeskripsikan dan meninjau tipologi elemen pada bangunan kolonial yang merupakan bangunan kunci dan menjadi ciri khas di koridor tersebut.

Upaya menemukenali identitas arsitektur juga merupakan tantangan bagi para arsitek untuk dapat menyajikan desain yang 'berkarakter' serta memiliki 'tempat' meminjam istilah Tuan (2001) agar terdapat resonansi yang muncul antara masyarakat kota dan ruang kotanya. Dalam hal ini, menurut Mangunwijaya (1992) bahwa berarsitektur sesungguhnya harus menaungi unsur guna dan citra penjelasan ini diperjelas lagi oleh Ridjal (2012) bahwa karya arsitektur harus dapat: memberi makna; yang mengindikasikan bahwa keterpaduan antara unsur materi dan immateri tidak bisa terpisahkan; menterjemahkan atau membahasakannya ke dalam jati diri pengguna.

Bentuk bangunan pertokoan pada kawasan harus kontekstual dengan lingkungan dengan memunculkan karakter arsitektur kolonial. Hal ini juga menjadi salah satu upaya dalam pemunculan identitas asli kawasan. Konsep bentuk pada kawasan adalah kontekstual dengan lingkungan dengan mengadopsi bentuk-bentuk dasar bangunan kolonial di kawasan basuki rahmat. Maka dari itu, di bawah ini akan dideskripsikan tipologi bangunan kolonial Belanda di Jalan Basuki rahmat, serta menganalisa karakter bangunan kolonial dengan elemen-elemen arsitektur pembentuknya.

Fasade bangunan pertokoan nantinya diharapkan dapat kontekstual dengan lingkungan sekaligus sebagai landmark kawasan jalan Basuki rahmat. Elemen-elemen pada bangunan ini mengacu pada bangunan kolonial sehingga terdapat kontinuitas visual di dalam kawasan. Elemen bangunan kolonial yang menonjol pada Jalan Basuki rahmat adalah elemen arsitektur menara.

Pada kawasan penelitian, selain menampilkan karakter bangunan kolonial di sepanjang jalan Basuki rahmat juga turut menampilkan ciri bangunan saat ini yang berkesan simple modern yang tentunya nantinya akan terjadi kombinasi antara kolonial dan modern dengan tetap memperhatikan konteks harmonisasi secara visual dan keseimbangannya. 


\section{Simpulan}

Penggalian identitas kota Malang melalui kawasan Kayu Tangan dapat ditelusuri melalui identifikasi historis bangunannya. Akan tetapi, perlu memperhatikan eksistensi bangunan sebagai citra kawassan kota tersebut. Dalam hal ini penataan wujud bangunan dan ruang luar (open space) khususnya dengan fokus di titik persimpangan jalan Basuki rahmat Malang mengacu pada jati diri dan identitas setempat yang didominasi oleh karakter dari bangunan kolonial yaitu dengan bentukan dominasi kotak, dengan garis vertikal dan horisontal yang kuat, sedangkan untuk ruang luar pada titik persimpangan khususnya pada perempatan kayu tangan mempunyai makna tertentu yaitu sebagai 'gate' atau pintu gerbang

Deretan bangunan kontekstual dengan lingkungan dirancang berdasarkan sistem lingkungan dan jati diri yang ada. Kontekstual dengan lingkungan juga diwujudkan dalam perancangan fasade bangunan yang mengadopsi bentuk bangunan yang spesifik dari bangunan konservasi di Jalan Basuki rahmat dan penataan jalur pedestriannya yang mengutamakan kenyamanan dan keamanan para penggunanya.

\section{Daftar Pustaka}

Ballantyne, Andrew. (2002). What is Architecture?. New York: Routledge

Budiharjo, Eko, (1997). Preservation and Conservation of Cultural Heritage in Indonesia. Gadjah Mada University Press, Yogyakarta

Edmund N. Bacon. (1974). Design of Cities. Viking Press: New York,.

Handinoto. (1996). Perkembangan Kota dan Arsitektur Kolonial Belanda di Surabaya 1870-1940. Kerjasama Lembaga Penelitian dan Pengabdian kepada Masyarakat Universitas Kristen Petra Surabaya dan Penerbit ANDI, Yogyakarta.

Handinoto, 2010. Arsitektur dan Kota-kota di Jawa pada Masa Kolonial. Graha Ilmu, Yogyakarta.

Lynch. K. (1960). The Image of the City. The Technology Press \& Harvard University Press. Cambridge

King, D. Anthony. (1976). Colonial Urban Development: culture, social power. Routledge \& Kegan Paul: London and Boston

Mangunwijaya. (1992). Wastu Citra: Pengantar ke Ilmu Budaya Bentuk Arsitektur Sendi-sendi Filsafatnya Beserta Contoh-contoh Praktis. Jakarta: Gramedia Pustaka Utama.

Rapoport, A. (1977). Human Aspects of Urban Form. Oxford: Pergamon Press

Ridjal, Abraham Mohammad. (2012). Membangun Jembatan Antara Buku Dan Praksis Arsitektur. Jurnal RUAS 10(2)

Ridjal, Abraham Mohammad. (2015). Memahami Makna Ruang Melalui 'SIMPUKNG'. Jurnal RUAS, 13(1)

Tuan, Yi-Fu. (2001). Space and Place: The Perspective of Experience. Minneapolis : Minesotta Press. 